\title{
Karakteristik Penderita Tuberkulosis di Wilayah Kerja Puskesmas Kinovaro Kabupaten Sigi
}

\author{
Christine \\ Jurusan Kesehatan Lingkungan, Poltekkes Kemenkes Palu, Indonesia \\ Email : christinekromoprawiro@gmail.com, HP: 085241079002
}

\begin{abstract}
Tuberculosis (TB) is a chronic bacterial infection caused by Mycobacterium tuberculosis, an acid-resistant bacillus that is transmitted through the air. The objective of this study is to know the description of the risk factors for the occurrence of Tuberculosis (TB) in the working area of Kinovaro Health Center, Kinovaro District, Sigi Regency. This research is a type of descriptive study with a large sample of 20 patients. Data collection was carried out using a direct observational approach using a questionnaire presented in tabular and narrative form. In this study the results obtained are the age of TB sufferers who are of productive age $70 \%$ and $30 \%$ of non-productive age, the sex of TB sufferers are $60 \%$ male and $40 \%$ female, the last education level is 65\% SD, 25\% SMP, and 10 SMA \%, smoking habits that smoke $25 \%$ and not smoke $75 \%$, occupancy density of rooms that meet the requirements of $30 \%$ and those that do not meet the requirements of $70 \%$.
\end{abstract}

Keywords : Risk factor, tuberculosis

\begin{abstract}
ABSTRAK
Tuberkulosis (TB) merupakan penyakit infeksi bakteri menahun yang disebabkan oleh Mycobacterium tuberculosis, suatu basil tahan asam yang ditularkan melalui udara. Tujuan penelitian ini adalah diketahuinya gambaran factor risiko kejadian Tuberkulosis (TB) di wilayah kerja Puskesmas Kinovaro Kecamatan Kinovaro Kabupaten Sigi. Penelitian ini merupakan jenis penelitian deskriptif. Populasi penelitian ini adalah pasien penderita penyakit Tuberkulosis (TB) di wilayah kerja Puskesmas Kinovaro berjumlah 20 orang penderita. Penelitian menggunakan sampling jenuh.Pengumpulan data dilakukan dengan pendekatan observasional langsung dengan menggunakan kuesioner yang disajikan dalam bentuk tabel dan narasi. Dalam penelitian ini didapatkan hasil yakni usia penderita TB yang usia produktif $70 \%$ dan usia tidak produktif $30 \%$, jenis kelamin penderita TB yang laki-laki $60 \%$ danperempuan $40 \%$, tingkat pendidikan terakhir yang SD $65 \%$, SMP $25 \%$, dan SMA $10 \%$, kebiasaan merokok yang merokok $25 \%$ dan tidak merokok $75 \%$, kepadatan hunian kamar yang memenuhi syarat $30 \%$ dan yang tidak memenuhi syarat $70 \%$.
\end{abstract}

Kata kunci : Faktor risiko, tuberkulosis

\section{PENDAHULUAN}

Tuberkulosis (TB) adalah penyakit yang disebabkan oleh basil tahan asam Mycobacterium tuberculosis dengan infeksi menahun. TB merupakan penyakit yang ditularkan melalui udara (airborne disease). Penyebarannya melalui transmisi udara berupa droplet dahak pasien penderita tuberkulosis sehingga. Droplet yang mengandung bakteri TB bisa berada di udara apabila pasien penderita TB batuk, bersin, atau berbicara. Bakteri atau kuman TB yang ada di udara dapat terhirup oleh orang lain di sekitar penderita TB sehingga terjadilah infeksi. Global Tuberculosis Report 2017 yang dirilis oleh badan kesehatan dunia WHO, memuat pernyataan bahwa TB termasuk adalah satu penyakit dari 10 penyebab kematian di dunia.TB juga menjadi penyebab utama kematian yang berhubungan dengan resintensi antimikroba (antimicrobial resestence) dan merupakan utama kematian penderita HIV. ${ }^{1}$

Salah satu faktor risiko kejadian TB ialah usia produktif. Usia produktif merupakan usia ketika seseorang berada pada fase untuk bekerja atau menghasilkan sesuatu, baik bagi diri sendiri maupun orang lain. Kelompok usia yang paling banyak menjadi penderita TB (sebanyak $75 \%$ ) adalah kelompok usia yang paling produktif secara ekonomi, yaitu 15-49 
tahun. Penyakit TB dapat mengakibatkan seseorang pada usia produktif menjadi individu yang tidak produktif bahkan menjadi beban bagi keluarganya. Seorang penderita TB pada kelompok usia dewasa diperkirakan akan kehilangan rata-rata waktu kerjanya 3 - 4 bulan, sehingga berdampak pada kondisi ekonomi keluarga akibat kehilangan pendapatan tahunan rumah tangga sekitar $20-30 \%{ }^{2}$

Faktor lain yang berhubungan dengan kejadian TB adalah tingkat pendidikan. Tingkat pendidikan berbanding terbalik dengan besar risiko seseorang untuk menderita TB. Semakin rendah pendidikan seseorang maka semakin besar risiko untuk menderita TB. Pendidikan memiliki korelasi dengan pengetahuan, dan pengetahuan berkorelasi dengan upaya seseorang untuk mencari pengobatan apabila menderita suatu penyakit. Pengetahuan yang dipengaruhi oleh tingkat pendidikan adalah salah satu faktor pencetus (predisposing) yang berkontribusi dalam pengambilan keputusan seseorang untuk berperilaku sehat.Semakin tinggi pendidikan seseorang maka pengetahuan tentang TB semakin baik. Peningkatan pengetahuan seseorang tenntang TB dapat meningkatkan upaya pengendalian dan preventif sehingga tidak terinfeksi bakteri TB dan juga upaya pengobatan jika terinfeksi. ${ }^{2}$

Subyek penelitian yang menderita Tuberkulosis (TB) cenderung lebih banyak berjenis kelamin laki-laki dibandingkan perempuan. Laki-laki sebanyak 40 orang $(54,8 \%)$ dan perempuan 33 orang (45,2\%). Prevalensi Tuberkulosis di Indonesia pada laki-laki dua kali lebih besar dibandingkan perempuan. ${ }^{3}$ Hasil penelitian yang dilakukan oleh Liauw dan Chen tentang TB menunjukkan dalam kurun waktu penelitian berlangsung di kalangan laki-laki kebiasaan merokok secara bermakna berhubungan dengan peningkatan risiko kematian secara umum dibandingkan dengan mereka yang tidak merokok. Pada perempuan kebiasaan merokok secara bermakna berhubungan dengan peningkatan angka kematian secara umum, bila dibandingkan dengan yang tidak merokok. ${ }^{4}$

Selain faktor individu, lingkungan rumah juga berperan penting dalam penularan bakteri TB. Bakteri TB mampu bertahan hidup 1-2 jam hingga beberapa hari. Kondisi ini dipengaruhi ada tidaknya sinar matahari, kondisi ventilasi, kelembaban, suhu rumah dan kepadatan hunian rumah. Luas rumah yang tidak sebanding dengan penghuninya akan mengakibatkan tingginya kepadatan hunian rumah. ${ }^{5}$ Penelitian tersebut menemukan bahwa rumah tangga yang memiliki lebih dari satu orang penderita dalam satu rumah memiliki risiko 4 kali tertular tuberkulosis dibanding rumah yang hanya memiliki satu penderita tuberkulosis. Sedangkan penelitian yang dilakukan Sugiharto, menyatakan terdapat hubungan bermakna antara kepadatan hunian rumah terhadap angka kejadian tuberculosis. ${ }^{6}$ Selain itu, Tobing menyatakan terdapat hubungan antara kepadatan hunian rumah terhadap potensi penularan tuberkulosis (TB).

Berdasarkan Profil Kesehatan Indonesia Tahun 2017 jumlah kasus penderita Tuberkulosis (TB) adalah 2.211 orang di Sulawesi Tengah. ${ }^{8}$ Berdasarkan data dari Dinas Kesehatan Kabupaten Sigi pada tahun 2015 jumlah penderita Tuberkulosis (TB) Di Kabupaten Sigi yaitu 166 orang, pada tahun 2016 jumlah penderita TB Di Kabupaten Sigi meningkat yaitu 210 orang, pada tahun 2017 jumlah penderita TB Di Kabupaten Sigi meningkat, yaitu 236 orang. ${ }^{9}$ Berdasarkan data penyakit Tuberkulosis (TB) tahun 2018 di wilayah kerja Puskesmas Kinovaro Kecamatan Kinovaro Kabupaten Sigi jumlah penderita Tuberkulosis (TB) adalah 20 orang. Di Puskesmas Kinovaro adalah salah satu Puskesmas yang mempunyai angka penyakit TB tertinggi diantara Puskesmas lainnya yang ada di Kabupaten Sigi, maka dari itu peneliti tertarik mengambil penelitian di wilayah kerja Puskesmas Kinovaro. ${ }^{10}$ Penelitian ini bertujuan untuk mengetahui gambaran faktor risiko kejadian Tuberkulosis (TB) di wilayah kerja Puskesmas Kinovaro Kecamatan Kinovaro Kabupaten Sigi.

\section{METODE PENELITIAN}

Jenis penelitian ini adalah deskriptif dengan pendekatan observasional yang bertujuan untuk mengetahui gambaran faktor risiko kejadian Tuberkulosis (TB) di wilayah kerja Puskesmas Kinovaro Kecamatan Kinovaro Kabupaten Sigi. Penelitian ini dilaksanakan pada bulan Maret 2019. Adapun lokasi penelitian di wilayah kerja Puskesmas Kinovaro 
Kecamatan Kinovaro Kabupaten Sigi. Populasi penelitian ini adalah pasien penderita penyakit Tuberkulosis (TB) di wilayah kerja Puskesmas Kinovaro berjumlah 20 orang penderita. Penelitian ini menggunakan sampling jenuh.

Pengumpulan data melalui sumber data primer penelitian diperoleh dengan wawancara kepada penderita Tuberkulosis (TB) dan keluarga penderita TB dan juga melakukan pengamatan langsung di lapangan, yaitu data usia, jenis kelamin, tingkat pendidikan, kepadatan hunian kamar, kebiasaan merokokdari penderita Tuberkulosis (TB). Data sekunder diperoleh dari catatan atau register Puskesmas Kinovaro yaitu data jumlah penyakit Tuberkulosis (TB) di wilayah kerja Puskesmas Kinovaro, Dinas Kesehatan Provinsi Sulawesi Tengah yaitu data profil kesehatan di Provinsi Sulawesi Tengah, dan Dinas Kesehatan Kabupaten Sigi yaitu data jumlah penyakit Tuberkulosis (TB) di Kabupaten Sigi. Analisis data dalam penelitian ini adalah analisa deskriptif yaitu untuk mendapatkan gambaran tentang faktor risiko kejadian Tuberkulosis (TB) di wilayah kerja Puskesmas Kinovaro Kecamatan Kinovaro Kabupaten Sigi.

\section{HASIL PENELITIAN}

Hasil penelitian tentang karakteristik penderita TB Paru ditampilkan dalam tabel 1.

Tabel 1. Karakteristik Penderita TB Paru

\begin{tabular}{lcc}
\multicolumn{1}{c}{ Variabel } & Frekuensi & Persen \\
\hline Jenis kelamin & 12 & \\
a. Laki-laki & 8 & $60 \%$ \\
b. Perempuan & & $40 \%$ \\
Umur & 14 & $70 \%$ \\
$\begin{array}{l}\text { a. Produktif (15-50 tahun) } \\
\text { b. Tidak produktif ( } \geq 51 \text { tahun) }\end{array}$ & 6 & $30 \%$ \\
Tingkat pendidikan & 13 & \\
a. SD & 5 & $65 \%$ \\
b. SMP & 7 & $25 \%$ \\
C. SMA & & $10 \%$ \\
Kebiasaan merokok & 5 & $25 \%$ \\
a. Ya & 15 & $75 \%$ \\
b. Tldak & & \\
\hline
\end{tabular}

Sumber: Data Primer, 2019

Hasil penelitian yang dilakukan di wilayah kerja Puskesmas Kinovaro menunjukkan bahwa dari 20 orang penderita kejadian Tuberkulosis (TB) kebanyakan penderita TB terdapat di usia produktif yaitu 14 orang penderita dan usia tidak produktif terdapat 6 orang penderita. Lebih banyak penderita TB paru berjenis kelamin laki-laki daripada perempuan. Kebanyakan penderita TB yang tingkat pendidikan terakhirnya rendah yang kurang mengetahui tentang kejadian TB terdapat 13 orang penderita di tingkat pendidikan terakhir SD, terdapat 5 orang penderita yang tingkat pendidikan terakhir SMP, dan terdapat 2 orang penderita yang tingkat pendidikan terakhir SMA. Lebih banyak penderita TB yang tidak merokok karena kebanyakan penderita yang dulunya merokok setelah terkena TB mereka berhenti merokok. Terdapat 15 orang penderita yang tidak merokok dan terdapat 5 orang penderita yang merokok.

Tabel 2. Kepadatan Hunian Rumah Penderita TB Paru

\begin{tabular}{ccc}
\hline Variabel & Frekuensi & Persen \\
\hline $\begin{array}{c}\text { Kepadatan hunian rumah } \\
\text { Memenuhi syarat }\end{array}$ & 6 & $30 \%$
\end{tabular}


Tidak memenuhi syarat

14

$70 \%$

Sumber: Data Primer, 2019

Tabel 2 menunjukkan bahwa dari 20 orang penderita kejadian Tuberkulosis (TB).Penderita TB yang memenuhi syarat sebanyak 6 orang penderita dan yang tidak memenuhi syarat sebanyak 14 orang penderita yaitu mempunyai faktor risiko kejadian TB. Rumah yang memenuhi syarat kesehatan adalah rumah dengan luas kamar $\geq 8 \mathrm{~m}^{2} / 2$ orang. Sedangkan, yang tidak memenuhi syarat kesehatan adalah rumah dengan luas kamar $<8$ $\mathrm{m}^{2} / 2$ orang.

\section{PEMBAHASAN}

Jenis kelamin adalah salah satu faktor kejadian Tuberkulosis (TB) dikarenakan lebih banyak penderita TB yang berjenis kelamin laki-laki dibandingkan dengan perempuan. Menurut penelitian Dotulong di Desa Wori Kecamatan Wori, terdapat asosiasi atau hubungan antara jenis kelamin dengan kejadian penyakit TB paru. Jenis kelamin laki-laki 6 kali lebih berisiko untuk terkena penyakit TB dibanding perempuan. ${ }^{12}$ Tingginya kasus TB pada terhadap laki-laki antara lain disebabkan juga oleh kebiasaan merokok yang banyak dilakukan oleh laki-laki, rokok yang dihisap oleh seseorang mengandung racun yang dapat merusak kesehatan sehingga mudah terinfeksi berbagai penyakit diantaranya bakteri tuberkulosis. ${ }^{13}$

Banyaknya jumlah kasus yang terjadi pada kelompok usia produktif dapat terjadi karena pada usia ini mayoritas orang banyak menghabiskan waktu dan tenaganya untuk bekerja, di mana tenaga banyak terkuras, waktu istirahatnya kurang sehingga daya tahan tubuh menurun. ${ }^{14}$ Risiko terbesar kejadian TB paru adalah pada usia dewasa, di mana pada usia tersebut adalah usia yang produktif. Kemungkinan hal ini disebabkan karena pada usia produktif mempunyai mobilitas yang tinggi (rata-rata masih bekerja) sehingga mempengaruhi daya tahan tubuh dan dapat menyebabkan terpaparnya kuman TB lebih besar. ${ }^{15}$ Penelitian oleh Triningtias tentang Pola Penyebaran Kasus Tuberkulosis Paru di Kelurahan Utama Kecamatan Cimahi Selatan Tahun 2018 juga menunjukkan 85\% kasus TB paru menyerang usia produktif. ${ }^{16}$ Usia berkaitan erat dengan kejadian Tuberkulosis (TB) mungkin disebabkan lingkungan kerja yang padat serta berhubungan dengan banyak orang juga dapat meningkatkan risiko terjadinya TB. Kondisi kerja yang demikian ini memudahkan seseorang yang berusia produktif lebih mudah dan lebih banyak menderita TB. ${ }^{12}$

Tingkat pendidikan berhubungan erat dengan pengetahuan, dari hasil yang diketahui setelah melihat atau menyaksikan, mengalami atau diajar, sehingga pendidikan yang relatif rendah menyebabkan keterbatasan informasi tentang gejala dan pengobatan Tuberkulosis (TB). ${ }^{17}$ Tingkat pendidikan terakhir menggambarkan perilaku seseorang dalam hal kesehatan. Semakin rendah pendidikannya maka ilmu pengetahuan dibidang kesehatan semakin berkurang, baik secara langsung maupun tidak langsung dapat mempengaruhi lingkungan fisik, biologis, dan sosial yang merugikan kesehatan dan akhirnya mempengaruhi tingginya kasus TB yang ada dan keteraturan minum obat. ${ }^{13}$

Kebiasaan merokok memperburuk gejala TB. Demikian juga dengan perokokpasif yang menghisap asap rokok, akan lebihmudah terinfeksi kuman TB. Karena asap rokokberdampak buruk pada daya tahan paru terhadap bakteri. Merokok merupakan penyebab utama penyakit paru-paru yang bersifat kronis dan obstrukti, misalnya bronkitis dan emfisema.Merokok juga terkait dengan influenza dan radang paru-paru lainnya.pada penderita asma, merokok akan memperparah gejala asma sebab asap rokok akan lebih menyempitkan saluran pernafasan. Efek merugikan tersebut mencakup meningkatnya kerentanan terhadap batuk kronis, produksi dahak dan serak.Hal ini dapat memperparah kondisi infeksi bakteri tuberkulosis. ${ }^{13}$

Dalam penelitian yang dilakukan oleh Ardhitya dan Liena menunjukkan tidak ada hubungan antara kebiasaan merokok dengan kejadian tuberkulosis. Hal ini dapat terjadi karena jumlah responden yang merokok lebih sedikit dibandingkan yang tidak merokok. Hal ini disebabkan responden yang diteliti pernah merokok namun sudah berhenti ketika terkena TB dan tidak merokok kembali. ${ }^{18} \mathrm{Hal}$ ini sesuai dengan penelitian yang menyatakan bahwa 
status kebiasaan merokok setiap hari tidak memiliki hubungan dengan kejadian tuberkulosis. ${ }^{19}$

Kepadatan penghuni merupakan salah satu faktor risiko TB di mana semakin padat rumah maka perpindahan penyakit, khususnya penyakit menular melalui udara akan semakin mudah dan cepat, apabila terdapat anggota keluarga yang menderita TB dengan BTA positif yang secara tidak sengaja batuk. Bakteri Mycobacterium tuberculosis akan menetap di udara selama kurang lebih 2 jam sehingga memiliki kemungkinan untuk menularkan penyakit pada anggota yang belum terpajan. ${ }^{12}$ Penelitian Prihanti dalam penelitiannya tentang Analisis Faktor Risiko TB Paru di wilayah kerja Puskesmas Pesantren II Kota Kediri pun memperoleh hasil yang serupa, yaitu kepadatan hunian merupakan salah satu faktor risiko kejadian TB paru. Hasil penelitiannya menunjukkan kepadatan hunian yang memenuhi syarat akan menurunkan risiko kejadian TB paru. ${ }^{20}$

\section{SIMPULAN DAN SARAN}

Kesimpulan yang penelitian ini diantaranya usia penderita kejadian Tuberkulosis (TB) kebanyakan terdapat pada usia yang produktif sebanyak 14 orang penderita. Jenis kelamin penderita kejadian Tuberkulosis (TB) kebanyakan terdapat pada yang berjenis kelamin lakilaki sebanyak 12 orang penderita. Tingkat pendidikan terakhir penderita kejadian Tuberkulosis (TB) kebanyakan terdapat pada yang tingkat pendidikan terakhir SD sebanyak 13 orang penderita yang masih kurang pengetahuan tentang kejadian TB. Kebiasaan merokok penderita kejadian Tuberkulosis (TB) kebanyakan terdapat pada yang tidak merokok sebanyak 15 orang penderita dikarenakan penderita yang lalunya merokok setelah terkena TB berhenti merokok. Kepadatan hunian kamar penderita kejadian Tuberkulosis (TB) kebanyakan terdapat tidak memenuhi syarat sebanyak 14 orang penderita.

Tenaga kesehatan Puskesmas Kinovaro untuk mengaktifkan kegiatan penyuluhan kesehatan kepada masyarakat mengenai faktor risiko kejadian Tuberkulosis (TB). Bagi institusi jurusan kesehatan lingkungan, diharapkan hasil penelitian ini dapat menjadi bahan atau materi pembelajaran. Bagi penelitian selanjutnya bagi penelitian sejenis yang berkaitan dengan Tuberkulosis (TB), sebaiknya mengambil lokasi penelitian yang berbeda dan menambahkan variabel yang lain.

\section{UCAPAN TERIMA KASIH}

Terima kasih Kepada Kepala Puskesmas Kinovaro yang telah memberikan izin kepada peneliti untuk melakukan penelitian di wilayah kerja Puskesmas Kinovaro Kecamatan Kinovaro Kabupaten Sigi.

\section{DAFTAR PUSTAKA}

1. WHO. Global Tuberculosis Report [Internet]. 2017 [cited 2021 May 17]. Available from: https://extranet.who.int/tme

2. Nurjana MA. Faktor Risiko Terjadinya Tubercolosis Paru Usia Produktif (15-49 Tahun) di Indonesia. Media Penelit dan Pengemb Kesehat. 2015;25(3):163-70.

3. Utami F, Salam A, Handoko W. Hubungan Usia, Jenis Kelamin, Tingkat Kepositifan dengan Konversi Basil Tahan Asam Pasien Tuberkulosis di Unit Pengobatan Penyakit Paru-paru Pontianak Periode 2009-2012. J Mhs PSPD FK Univ Tanjungpura. 2014;1(1):1-17.

4. Liauw K, Chen C. Mortalitas Akibat Merokok di Taiwan; Suatu Studi Prospektif Selama 12 Tahun [Internet]. [cited 2021 May 17]. Available from: https://www.klikpdpi.com/jurnal-warta/rokok/rokok-kes-03.html

5. Sukana B, Soesanto SS, Atmosukarto K. Pengaruh Lingkungan Perumahan Penduduk Penderita TB Paru Terhadap Angka Bakteri Tahan Asam (BTA) pada Perumahan di DT II Kabupaten Tangerang. Media Litbang Kesehat. 2000;IX(4):22-7.

6. Sugiharto. Hubungan Kepadatan Hunian Rumah dengan Kejadian Penyakit Tuberkulosis Paru di Puskesmas Jenggot. Universitas Diponegoro; 2004. 
7. Tobing TL. Pengaruh Perilaku Penderita TB Paru dan Kondisi Rumah terhadap Pencegahan Potensi Penularan TB Paru pada Keluargadi Kabupaten Tapanuli Utara. Universitas Sumatera Utara; 2008.

8. $\quad$ Kementerian Kesehatan RI. Profil Kesehatan Indonesia Tahun 2017. 2018.

9. Dinas Kesehatan Provinsi Sulawesi Tengah. Profil Kesehatan Provinsi Sulawesi Tengah Tahun 2017. Palu; 2018.

10. Dinas Kesehatan Kota Palu. Kabupaten Sigi Tahun 2014. Frofil Dinas Kesehat Kota Palu. 2014;

11. Indonesia KKR. Keputusan Menteri Kesehatan Republik Indonesia Nomor 829 Tahun 1999 tentang Persyaratan Kesehatan Perumahan. Jakarta; 1999.

12. Dotulong JFJ, Sapulete MR, Kandou GD. Hubungan faktor risiko umur, jenis kelamin dan kepadatan hunian dengan kejadian penyakit tb paru di desa wori kecamatan wori. :57-65.

13. Muaz. Faktor-faktor Yang Mempengaruhi Kejadian Tuberkulosis Paru Basil Tahan Asam Positif di Puskesmas Wilayah Kecamatan Serang Kota Serang Tahun 2014. Universitas Islam Negeri Syarif Hidayatullah; 2014.

14. Mahfuzhah I. Jurnal Mahasiswa PSPD FK Universitas Tanjungpura. 2014;1(1):1-13.

15. Suarni. Faktor Risiko Yang Berhubungan dengan Kejadian Penderita Penyakit TB Paru BTA Positif di Kecamatan Pancoran Mas Kota Depok. Universitas Indonesia; 2009.

16. Triningtias AY, Putri THK. Pola Penyebaran Tuberkulosis Paru di Kelurahan Utama Kecamatan Cimahi Selatan Tahun 2018. Med Kartika J Kedokt dan Kesehat. 2019;2(2):98-109.

17. Kementerian Kesehatan RI. Pedoman Nasional Pengendalian Tuberkulosis. Jakarta: Kementerian Kesehatan RI; 2011.

18. Sejati A, Sofiana L. Faktor-faktor Terjadinya Tuberkulosis. J Kesehat Masy. 2015;10(2):122-8.

19. Widyasari RN. Hubungan Antara Jenis Kepribadian, Riwayat Diabetes Melitus dan Riwayat Paparan Rokok dengan Kejadian TB Paru Dewasa di Wilayah Kecamatan Semarang Utara Tahun 2011. Universitas Diponegoro; 2011.

20. Prihanti GS, Sulistiyawati, Rahmawati I. Analisis Faktor Risiko Kejadian Tuberkulosis Paru. Saintika Med J IImu Kesehat dan Kedokt Kel. 2015;11(2):127-32. 